\title{
Planning of coal production taking into account the intensity of shipment and the capacity of transport routes
}

\author{
Alexey Tyurin $^{1 *}$, and Akhmetgalym Tlek Akhmetgalymuly ${ }^{2}$ \\ ${ }^{1}$ T.F. Gorbachev Kuzbass State Technical University, Department of Automobile Transportation, \\ 650000 Kemerovo, 28 Vesennyaya st., Russian Federation \\ ${ }^{2}$ Kazakh Humanitarian Law Innovative University, Department of Information and Technical \\ Sciences, EKR, Semey, 11Mangilik st., Republic of Kazakstan
}

\begin{abstract}
For effective planning of coal mining at coal mines, it is necessary to take into account the relationship between internal and external processes that occur from the moment of mining the coal to the moment of its sale to consumers. Internal processes are primarily determined by the coordination of operations for drilling and blasting operations, the excavation of mined rock into dumps, the movement of coal to warehouses, its washing and further shipment to railway wagons. External processes are determined by ensuring the delivery of coal to consumers, taking into account the capacity of transport routes, the demand for coal and the price policy in export markets that develops in a certain period of time. Using the example of coal companies that are part of JSC Kuzbassrazrezugol, the article considers a two-level dynamic model for planning coal production, taking into account the intensity of shipment and the capacity of transport routes. At the first level, the volume of coal production intended for export is determined by month, taking into account the intensity of demand for the periods of the year and all restrictions that affect the speed of coal movement to the consumer. At the second level of the system under consideration, the volume of coal sales for export is redistributed over a single time period, taking into account the limitations in the capacity of transport routes, the speed of cargo delivery to the consumer, the level of demand and prices for coal. The use of the dynamic programming method made it possible to solve the problem of redistributing coal sales volumes for export at the second level and, using the results of solving this problem, to determine the optimal volumes of coal production intended for export at the first level.
\end{abstract}

\section{Introduction}

The development of the coal industry, especially in open-pit mining, is subject to numerous random factors, including climatic, environmental, technological [1 - 4], economic [5 - 10],

\footnotetext{
* Corresponding author: alexturin07@rambler.ru
} 
social, medical (COVID-19), and other factors. The main indicator of the coal industry enterprises activity is the profit generated as a result of the enterprises activities (for example, open-pit) in the management of technological processes of the enterprise full life cycle from the moment of opening the quarry field to the moment of land reclamation.

The management of technological processes is primarily based on the planning of coal mining [11, 12, 13], taking into account the available production, transport, loading, processing, storage, labor, financial and other resources $[15,16,17]$. The use of logistics principles makes it possible to coordinate actions between different divisions of a mining enterprise [18], as a result of which the total costs of mining, processing and transporting coal to consumers are reduced. The results of such coordination make it possible to effectively use the production capacity for the extraction of solid minerals.

An even greater economic effect can be achieved by considering the activities of a coal mine from the position of a two-level dynamic system [19]. Schematically, the tasks of the levels are presented in Table 1. In this case, the first level determines the volume of coal production intended for export by month, taking into account the intensity of demand for the periods of the year and all restrictions that affect the speed of movement of coal to the consumer. At the second level of the system under consideration, the volume of coal sales for export is redistributed over a single time period, taking into account the limitations in the capacity of transport routes, the speed of cargo delivery to the consumer, the level of demand and prices for coal. Thus, a change in the operating conditions of a coal mine at the first level (a change in the speed of coal shipment to railway cars, a shortage of cars themselves, a decrease in the speed of delivery due to restrictions on the capacity of transport routes) leads to a change in the speed of coal production, which, in turn, at the second level leads to a change in the conditions for selling coal in the directions of transportation, taking into account all possible restrictions.

Table 1. Two-level planning system for coal mining, taking into account the intensity of shipment and the capacity of transport routes.

\begin{tabular}{|c|l|}
\hline Level 1 & $\begin{array}{l}\text { Planning of coal production taking into account the intensity of its sales by } \\
\text { period of the year }\end{array}$ \\
\hline Level 2 & $\begin{array}{l}\text { Planning the redistribution of coal sales volumes for export in the } \\
\text { directions of transportation within one time period }\end{array}$ \\
\hline
\end{tabular}

\section{Materials and methods}

The object of the study is an open method of mining, in particular, the activities of the coal mines of Kuzbass, which are part of JSC Kuzbassrazrezugol.

To ensure efficient coal production, first of all, it is necessary to focus on the existing and projected demand. Coal supplies by the companies of JSC Kuzbassrazrezugol are carried out in domestic traffic to Russian consumers and for export in the eastern direction to the countries of Southeast Asia, in the western, northern and southern directions - to the countries of Europe and North Africa. Coal is shipped through seaports and border railway stations. The approximate ratio of shipping options by type of shipment and destination is shown in Figures 1 and 2. 


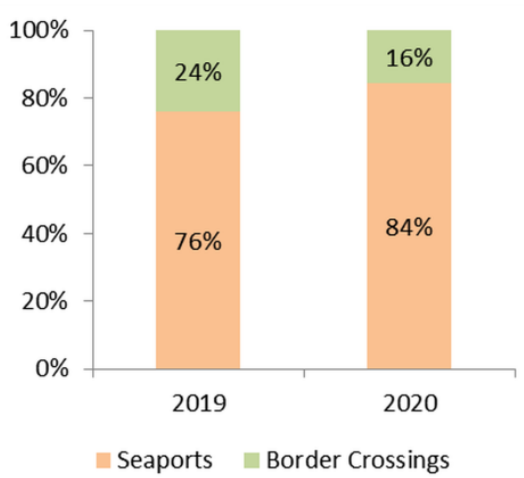

Fig. 1. Structure of coal shipments through seaports and railway border crossings for 2019-2020.

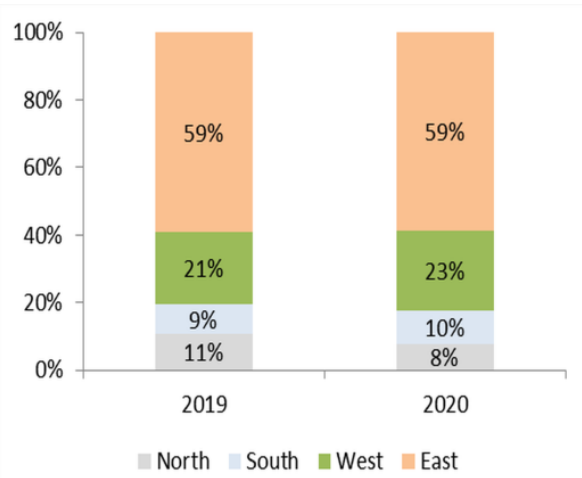

Fig. 2. Structure of coal export shipments in various directions for 2019-2020.

The dynamics of coal production, the total volume of shipments, the volume of shipments to the export direction of the coal companies of JSC Kuzbassrazrezugol are shown in Tables 2-4.

Table 2. Coal production dynamics for 2014-2020.

\begin{tabular}{|c|c|c|c|c|c|c|c|}
\hline Year & 2014 & 2015 & 2016 & 2017 & 2018 & 2019 & 2020 \\
\hline $\begin{array}{c}\text { Coal production } \\
\text { volume (million tons) }\end{array}$ & 44,0 & 44,5 & 45,3 & 47,2 & 48,4 & 47,0 & 43,2 \\
\hline
\end{tabular}

Table 3. Dynamics of total coal shipments for 2014-2020.

\begin{tabular}{|c|c|c|c|c|c|c|c|}
\hline Year & 2014 & 2015 & 2016 & 2017 & 2018 & 2019 & 2020 \\
\hline $\begin{array}{c}\text { Coal shipment volume } \\
\text { (million tons) }\end{array}$ & 42,4 & 41,8 & 40,4 & 43,0 & 42,8 & 43,9 & 40,7 \\
\hline
\end{tabular}

Table 4. Dynamics of coal export shipments for 2014-2020.

\begin{tabular}{|c|c|c|c|c|c|c|c|}
\hline Year & 2014 & 2015 & 2016 & 2017 & 2018 & 2019 & 2020 \\
\hline $\begin{array}{c}\text { Coal export volume } \\
\text { (million tons) }\end{array}$ & 30,2 & 30,0 & 29,2 & 30,4 & 30,0 & 31,3 & 27,4 \\
\hline
\end{tabular}

Coal prices in the west direction are based on the API 2 CIF ARA (Argus/McCloskey's Coal Price Index) indices, and in the east direction - on the API 8 CFR China (Argus/McCloskey's Coal Price Index) indices. They are based on contract prices based on the basic terms of delivery of FOB Incoterms-2020 [20], which are used for shipment in the western direction through the Russian ports of Murmansk, Vysotsky, etc. and in an easterly direction through the ports of Vanino, Nakhodka, etc. The dynamics of the average monthly prices for thermal coal is shown in Figure 3. 


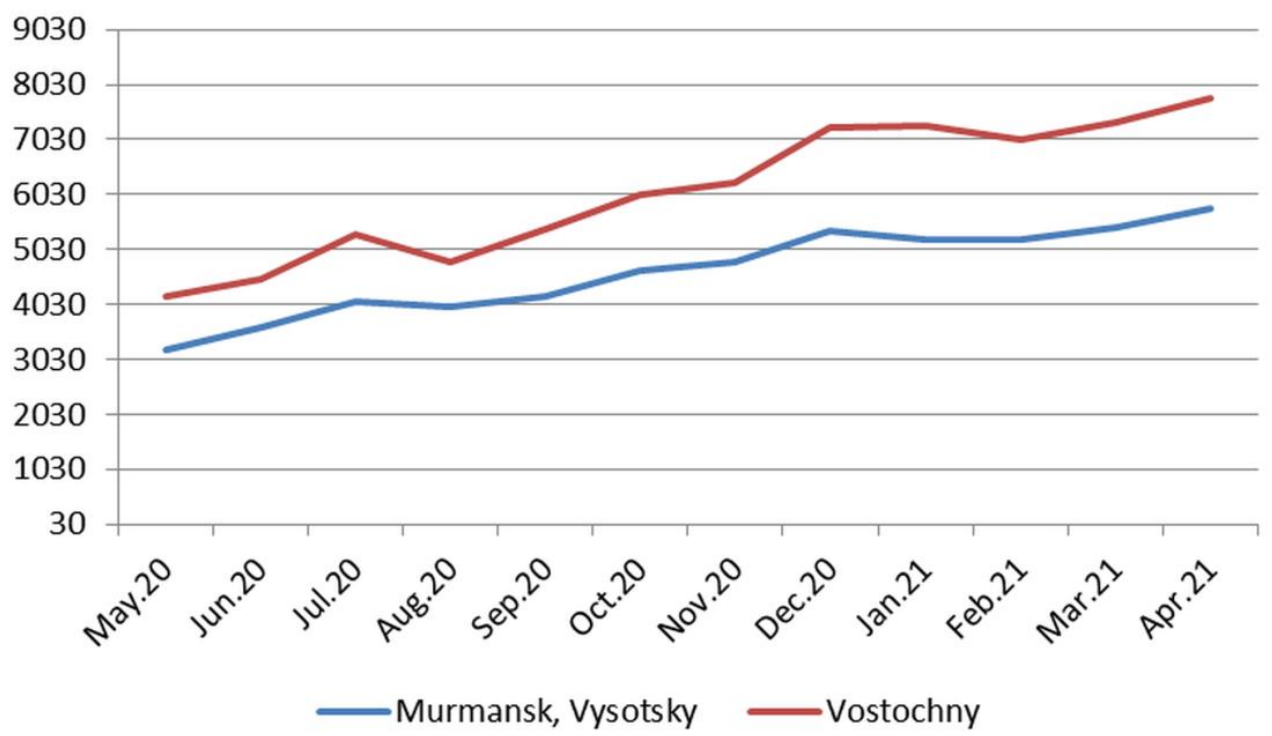

Fig. 3. Dynamics of average monthly prices for thermal coal (rubles / ton).

Maintaining a certain rhythm of coal shipment to railway transport allows you to maintain a certain rate of mineral extraction at the mines. The productivity of coal mining is also significantly affected by the speed of delivery to the consumer (the speed of sales/emptying of the warehouse), which depends on the distance of delivery, the direction of transportation and the congestion of transport routes. Thus, the coal companies of JSC Kuzbassrazrezugol ship coal from the mines to the railway stations Meret, Terentyevskaya, Yerunakovo, etc. Information on the speed of delivery of coal from Kuzbass for export is presented in Table 5. From the presented data, we can see a significant unevenness in the speed of coal delivery in the corresponding direction, which affects the intensity of its production and sales.

Table 5. Speed of coal delivery from Kuzbass for export.

\begin{tabular}{|c|c|c|c|c|c|c|c|c|c|c|c|}
\hline \multirow[b]{3}{*}{$\begin{array}{l}\text { Direction of } \\
\text { transportation }\end{array}$} & \multicolumn{4}{|c|}{$\begin{array}{l}\text { to the ports of the } \\
\text { Russian Far East }\end{array}$} & \multicolumn{2}{|c|}{$\begin{array}{l}\text { to China via } \\
\text { railway } \\
\text { border } \\
\text { crossings } \\
\end{array}$} & \multicolumn{3}{|c|}{$\begin{array}{l}\text { to the ports of } \\
\text { the north-west } \\
\text { of Russia }\end{array}$} & \multicolumn{2}{|c|}{$\begin{array}{l}\text { to the ports } \\
\text { of the south } \\
\text { of Russia }\end{array}$} \\
\hline & \multicolumn{11}{|c|}{ Destination Station } \\
\hline & 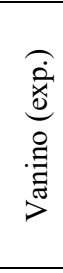 & 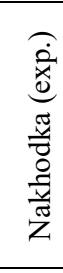 & 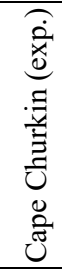 & 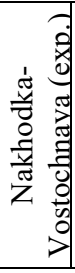 & 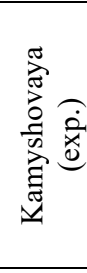 & 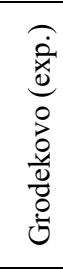 & 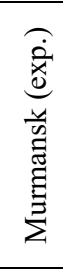 & 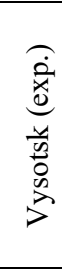 & 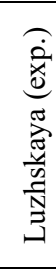 & 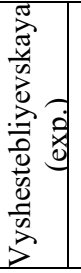 & 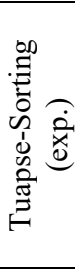 \\
\hline Departure station & \multicolumn{11}{|c|}{ Average turnover until the next loading, days } \\
\hline Yerunakovo & 24 & 27 & & 24 & 25 & & 16 & 16 & 17 & 15 & \\
\hline Meret & 26 & & 2 & 24 & 25 & 17 & & 16 & 18 & 18 & 22 \\
\hline Terentyevskaya & 24 & & & 24 & 27 & & 16 & 15 & 19 & 15 & \\
\hline Bochaty & 23 & & & 24 & & & & & 15 & & 27 \\
\hline Latyshi & & & & & & & & & 18 & & 25 \\
\hline
\end{tabular}


In the eastern direction, there are restrictions on the export of coal from the mines of JSC Kuzbassrazrezugol, established by the order of the Ministry of Energy of the Russian Federation and depending on the capacity of railway lines (Figure 4).

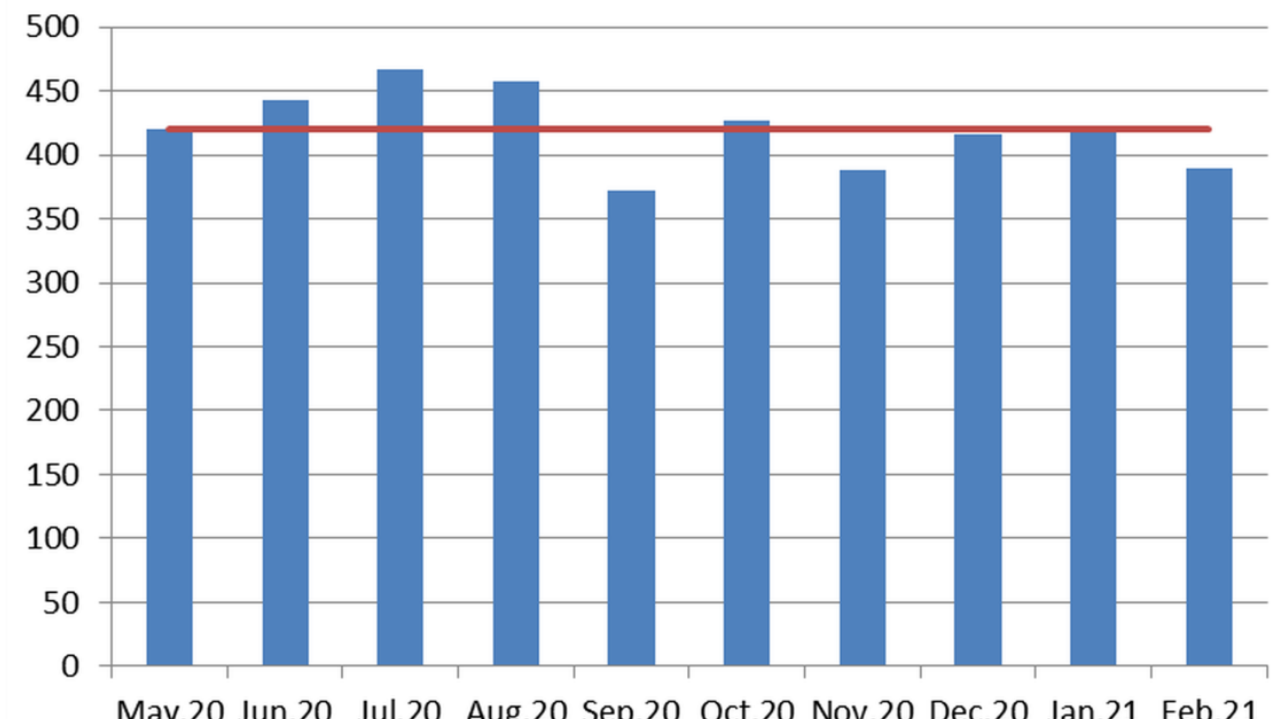

Fig. 4. Plan for the export of coal transportation by rail in the eastern direction (wagons/day) in 20202021.

In Figure 4, a horizontal line is drawn, which sets the average value of passing wagons by periods ( 420 wagons per day). At the same time, the standard deviation is 30 wagons per day with a coefficient of variation of $7 \%$. This information will allow you to coordinate the production program of coal mining with its further delivery to consumers for the periods of the year.

Let us consider the mathematical formulation of the problems of controlling the main processes of a two-level system of a coal mine. First, let's consider the statement for level 2, which details the processes of selling coal to consumers in detail. At this level, 11 transport routes are used to the corresponding destination stations (see table 5). As a basic unit of measurement, the route dispatch by railway rolling stock in the amount of 3,960 tons is accepted. We will introduce the following notation: $x_{i}$ - the number of route shipments in the $i$-th direction; $v_{i}$ - revenue in the $i$-th direction for the implementation of $x_{i}$ route shipments; $w_{i}$ — the rate of loading of the route in the $i$-th direction (3960 tons); $B$ - the total volume of coal delivery for export per month; $b_{i}^{\max }$ - the maximum volume that can be realized in the $i$-th direction; $p_{i}$ - the probability of realizing the volume of coal supply at the average level of demand $\overline{x_{i}}$ and the standard deviation $\delta_{i}$ in the $i$-th direction (the normal distribution law); $T_{i}$ — the capacity of transport routes for the delivery of coal for export in the $i$-th direction.

The objective function is to maximize the total revenue from the sale of coal in all directions and is expressed as follows:

$$
\sum_{i=1}^{11} v_{i} x_{i} \rightarrow \max
$$

under restrictions

$$
\sum_{i=1}^{11} x_{i} w_{i} \leq B
$$




$$
\begin{array}{r}
x_{i} w_{i} \leq b_{i}^{\max }, i=1, \ldots, 11 \\
x_{i} \geq 0, \quad i=1, \ldots, 11
\end{array}
$$

The problem can be solved by dynamic programming using the following recurrent

$$
f_{i}(B)=\max _{x_{i}}\left[v_{i} x_{i}+p_{i} f_{i-1}\left(B-b_{i}^{\max }\right], i=1, \ldots, 11\right.
$$

Scope of variable change $x_{i} \in\left[0 ; \min \left\{b_{i}^{\max } / w_{i} T_{i} / w_{i}\right\}\right], \mathbf{i}=\mathbf{1}, \ldots, \mathbf{1 1}$.

The task of level 1 is to determine the volume of coal production by month of the year and get the maximum profit, taking into account the preliminary distribution of volumes in the directions of transportation in the task of level 2.

Let's consider the mathematical formulation of the level 1 problem in managing the processes of coal production and sales for 10 months. To do this, we will introduce the following notation: $\boldsymbol{x}_{\boldsymbol{i}}$ - the volume of coal production in the $i$-th month, intended for export shipment; $\boldsymbol{c}_{\boldsymbol{i}}$ - the average cost of coal production in the $i$-th month; $\boldsymbol{c}_{\boldsymbol{i}}^{\boldsymbol{r}}$ - the average railway tariff in the $i$-th month for the delivery of coal for export; $\boldsymbol{v}_{\boldsymbol{i}}$ - income from the sale of coal for export in the $i$-th month; $\boldsymbol{y}_{\boldsymbol{i}}$ - the volume of coal sales for export in the $i$-th month; $\boldsymbol{Z}$ - the initial stock of coal in warehouses in the $i$-th month; $\boldsymbol{S}$ - the maximum capacity of coal warehouses.

The objective function is expressed as follows:

$$
\sum_{i=1}^{10} v_{i} y_{i}-c_{i} x_{i}-c_{i}^{r} y_{i} \rightarrow \max
$$

under restrictions

$$
\begin{gathered}
Z+x_{i}-y_{i} \leq S, \quad i=1, \ldots, 10 \\
x_{i} \geq 0, \quad i=1, \ldots, 10
\end{gathered}
$$

The problem can be solved by dynamic programming using the following recurrent expressions

$$
f_{i}(Z)=\max _{x_{i}}\left[v_{i} y_{i}-c_{i} x_{i}-c_{i}^{r} y_{i}+f_{i-1}\left(Z+x_{i}-y_{i}\right)\right], \quad i=1, \ldots, 10
$$

Scope of variable change $Z+y_{i} \leq x_{i} \leq S-Z+y_{i}, \quad i=1, \ldots, 10$.

In this problem, the parameters $v_{i}$ and $y_{i}$ are taken from the results of solving the level 2 problem.

\section{Results and discussion}

Using mathematical statements of problems, we will consider their practical implementation. The initial data for the level 2 task is presented in Table 6. The task is solved for each month of coal sales for export, taking into account the capacity of the eastern direction, restrictions in demand and coal prices in the corresponding directions. For example, for August 2020, the optimal results are shown in Table 7.

The analysis of the results of solving the level 2 problem shows that the restriction on the capacity of transport highways worked in all directions. As a result, it was not possible to meet all the demand for coal, so it is necessary to reduce the level of production in the month due to the existing surpluses in warehouses. At the same time, the average revenue per 1 ton of cargo transported will be 4305.5 rubles/ton and the total volume of export deliveries for August 2020 will be 550 route shipments. This data is then used as the 
parameters of the Level 1 task. Similarly, using the corresponding data, as in Table 6, the distribution volumes for the other months of the year are determined.

Table 6. Initial data for solving the problem of coal supplies distribution volumes for export by transportation directions.

\begin{tabular}{|c|c|c|c|c|c|c|c|}
\hline No. & $\begin{array}{c}\text { Direction of } \\
\text { transportation }\end{array}$ & $\begin{array}{c}\boldsymbol{v}_{\boldsymbol{i}}, \\
\text { rubles/ } \\
\text { ton }\end{array}$ & $\begin{array}{c}\boldsymbol{w}_{\boldsymbol{i}}, \\
\text { tons }\end{array}$ & $\begin{array}{c}\boldsymbol{b}_{\boldsymbol{i}}^{\text {max }}, \\
\text { r. d. }\end{array}$ & $\begin{array}{c}\boldsymbol{T}_{\boldsymbol{i}}, \\
\text { r. d. }\end{array}$ & $\begin{array}{c}\overline{\boldsymbol{x}_{\boldsymbol{i}}}, \\
\text { r. d. }\end{array}$ & $\begin{array}{c}\boldsymbol{\delta}_{\boldsymbol{i}}, \mathrm{r} . \\
\text { d. }\end{array}$ \\
\hline 1 & Vanino (export) & 4800 & 3960 & 60 & 35 & 50 & 10 \\
\hline 2 & Nakhodka (export) & 4800 & 3960 & 70 & 35 & 60 & 10 \\
\hline 3 & Cape Churkin (export) & 4800 & 3960 & 70 & 35 & 60 & 10 \\
\hline 4 & $\begin{array}{c}\text { Nakhodka- } \\
\text { Vostochnaya (export) }\end{array}$ & 4800 & 3960 & 80 & 35 & 70 & 10 \\
\hline 5 & $\begin{array}{c}\text { Kamyshovaya } \\
\text { (export) }\end{array}$ & 4800 & 3960 & 70 & 35 & 60 & 10 \\
\hline 6 & Grodekovo (export) & 4800 & 3960 & 70 & 35 & 60 & 10 \\
\hline 7 & Murmansk (export) & 4000 & 3960 & 70 & 68 & 60 & 10 \\
\hline 8 & Vysotsk (export) & 4000 & 3960 & 70 & 68 & 60 & 10 \\
\hline 9 & Luzhskaya (export) & 4000 & 3960 & 70 & 68 & 60 & 10 \\
\hline 10 & $\begin{array}{c}\text { Vyshestebliyevskaya } \\
\text { (export) }\end{array}$ & 4000 & 3960 & 70 & 68 & 60 & 10 \\
\hline 11 & $\begin{array}{c}\text { Tuapse-Sorting } \\
\text { (export) }\end{array}$ & 4000 & 3960 & 70 & 68 & 60 & 10 \\
\hline
\end{tabular}

Note: r. d.- route dispatch of a railway train with a weight norm of 3960 tons.

Table 7. Optimal volumes of coal distribution for export by transportation directions for August 2020.

\begin{tabular}{|c|c|c|c|c|c|c|c|c|c|c|c|}
\hline \multirow{2}{*}{$\begin{array}{c}\text { Indi- } \\
\text { cator }\end{array}$} & \multicolumn{10}{|c|}{ Direction of transportation } \\
\cline { 2 - 11 } & 1 & 2 & 3 & 4 & 5 & 6 & 7 & 8 & 9 & 10 & 11 \\
\hline $\begin{array}{c}x_{i}, \\
\text { r. d. }\end{array}$ & 35 & 35 & 35 & 35 & 35 & 35 & 68 & 68 & 68 & 68 & 68 \\
\hline
\end{tabular}

The solution to the level 1 task is to determine the optimal volumes of coal production intended for export. The initial data for the problem under consideration are presented in Table 8 . When solving the problem, the results of solving the level 2 problem are taken into account - the indicators $\boldsymbol{v}_{\boldsymbol{i}}$ and $\boldsymbol{y}_{\boldsymbol{i}}$ presented in columns 3 and 4 of Table 8 .

The optimal volumes of coal production (solution of the problem) are presented in the last column of Table 8 and in Figure 5. 
Table 8. Initial data and results of solving the problem of determining the optimal coal production volumes by month.

\begin{tabular}{|c|l|r|r|r|r|c|}
\hline \multirow{2}{*}{ No. } & \multicolumn{1}{|c|}{ Month } & \multicolumn{4}{|c|}{ Initial data } & Result \\
\cline { 3 - 7 } & & $\begin{array}{c}\boldsymbol{v}_{\boldsymbol{i}}, \\
\text { rubles/ } \\
\text { ton }\end{array}$ & $\begin{array}{c}\boldsymbol{y}_{\boldsymbol{i}}, \\
\text { r. d. }\end{array}$ & $\begin{array}{c}\boldsymbol{c}_{\boldsymbol{i}}, \\
\text { rubles/ } \\
\text { ton }\end{array}$ & $\begin{array}{c}\boldsymbol{c}_{\boldsymbol{i}}^{\boldsymbol{r}}, \\
\text { rubles/ } \\
\text { ton }\end{array}$ & $\begin{array}{c}\boldsymbol{x}_{\boldsymbol{i}}, \\
\text { tons }\end{array}$ \\
\hline 1 & August 2020 & 4305,5 & 550 & 2442,82 & 1736,9 & 2178000 \\
\hline 2 & September 2020 & 4628 & 560 & 2479,88 & 1736,9 & 2197600 \\
\hline 3 & October 2020 & 5247,4 & 550 & 2488,43 & 1736,9 & 2198000 \\
\hline 4 & November 2020 & 5406,3 & 570 & 2536,9 & 1736,9 & 2157200 \\
\hline 5 & December 2020 & 5997,1 & 530 & 2508,39 & 1736,9 & 2198800 \\
\hline 6 & January 2021 & 5980 & 560 & 2501,91 & 1736,9 & 2197600 \\
\hline 7 & February 2021 & 5818,1 & 530 & 2569,29 & 1736,9 & 2118800 \\
\hline 8 & March 2021 & 6154 & 560 & 2583,77 & 1736,9 & 2197600 \\
\hline 9 & April 2021 & 6516 & 560 & 2563,04 & 1736,9 & 2197600 \\
\hline 10 & May 2021 & 6457,8 & 520 & 2588,66 & 1736,9 & 2099200 \\
\hline
\end{tabular}

Note: r. d.- route dispatch of a railway train with a weight norm of 3960 tons.

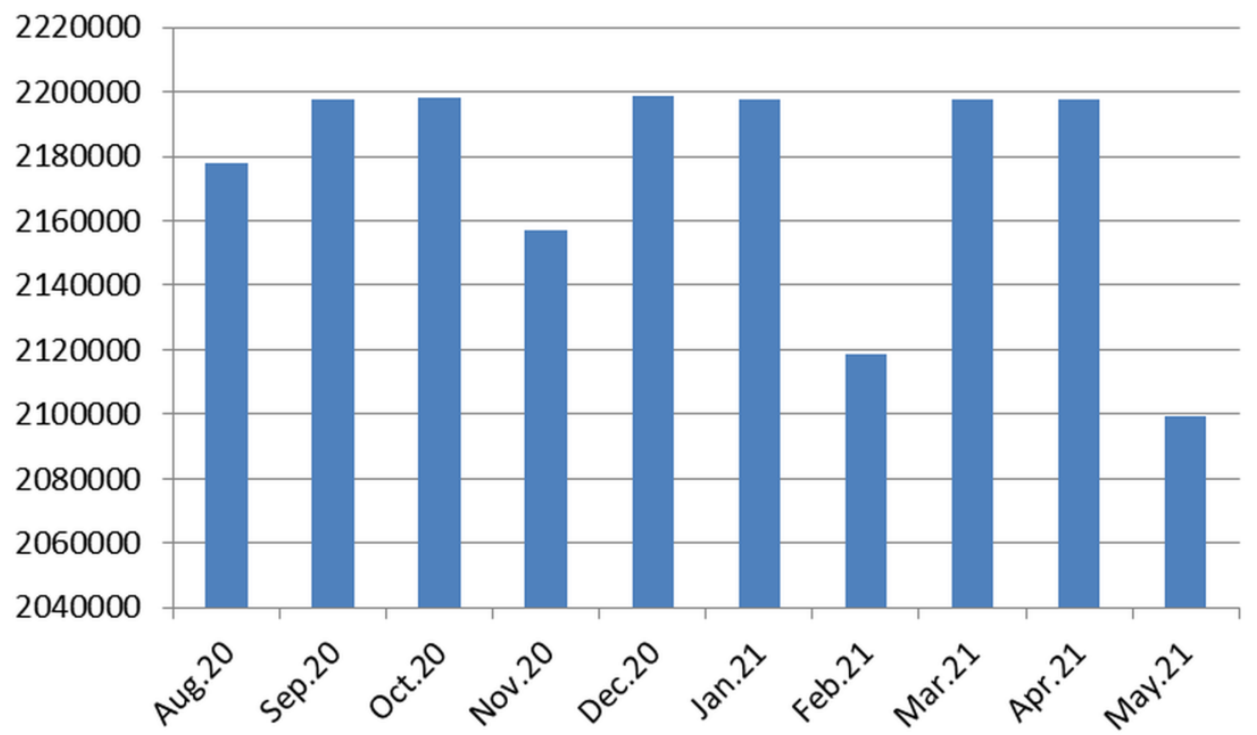

Fig. 5. Optimal volumes of coal production intended for export by month (tons).

Analysis of the results of solving the level 1 problem shows (Figure 5) that over 10 months, production should be uneven and vary in the range from 2099200 tons in May 2021 to 2197600 tons in September, October, December 2020 and in January, March, April 2021. Such flexible production management will allow you to get the maximum profit in the amount of 30050828000 rubles for 10 months. 


\section{Conclusion}

The use of a two-level planning system for coal production, taking into account the intensity of shipment and the capacity of transport routes, will allow for flexible use of existing production capacities, coordinate the processes of performing individual operations within the coal mine divisions, ensure the interconnection of internal and external processes of production and promotion of coal to the consumer, taking into account the level of demand.

Changes in the conditions of coal consumption, revision of prices for it, an increase in the speed of shipment, the capacity of transport routes, especially in the eastern direction, leads to the recalculation of the optimal volumes of coal distribution for export in the directions of transportation (level 2), and then on the basis of the optimal results obtained at level 2, the optimal volumes of coal production intended for export are calculated by month (level 1). As a result, the maximum profit of coal companies for the considered period of time is achieved, taking into account production, storage, transport and other restrictions.

The work is executed within the limits of the complex scientific and technical program of a full innovative cycle "Development and introduction of a complex of technologies in areas of exploration and extraction of solid minerals, maintenance of industrial safety, bioremediation, creation of new products of deep processing from coal raw materials at consecutive decrease in ecological impact on environment and risks for population life" (CSTP "Clean coal — Green Kuzbass") on event $\mathbf{2 . 5}$ "Development and creation of an autonomous shuttle-type dump truck with carrying capacity of 220 tons (JUPITER project)", with participation of T.F. Gorbachev Kuzbass State Technical University in terms of research, development and technological works.

\section{References}

1. Alarie S., Gamache M., Int J Surf Min Reclamat Environ 16, 59 (2002)

2. Ta C.H., Kresta J.V., Forbes J.F., Marquez H.J., Int J Surf Min Reclamat Environ 19, $162(2005)$

3. Krause A., Musingwini C., J S Afr Inst Min Metall 107, 469 (2007)

4. Burt C.N., Caccetta L., Int J Surf Min Reclamat Environ 21, 263 (2007)

5. Dimitrakopoulos, R., J Min Sci 47(2), 138 (2011)

6. Groeneveld B., Topal E., J Min Sci 47(2), 212 (2011)

7. Topal E., Ramazan S., J Coal Sci Eng 18(3), 313 (2012)

8. Onur, A. H., Dowd, P. A., Trans Inst Min Metall 102, 105 (1993)

9. Erarslan, K., Celebi, N., CIM Bull 94, 59 (2001)

10. Elveli, B., Int J Surf Min Reclamat Environ 9, 149 (1995)

11. Kear, R., J S Afr I Min Metall 106, 93 (2006)

12. King, B., J Min Sci+ 47(2), 247 (2011)

13. Osanloo, M., Gholamnejad, J., Karimi, B., Int J Min Reclam Env 22(1), 2 (2008)

14. Dubinkin D.M., Sadovets V.Yu., Kotiev G.O., Kartashov A.V. Journal of mining and geotechnical engineering, 4(7),50 (2019)

15. Dubinkin D.M. Mining Equipment and Electromechanics. 4, 59 (2020)

16. Dubinkin D., Aksenov V., Tyulenev M., Markov S. Journal of mining and geotechnical engineering. 4, 42 (2020)

17. M.A. Tyulenev, S.O. Markov, D.M. Dubinkin, V.V. Aksenov. Herald KuzSTU. 1, 97 (2021)

18. Tyurin, A., E3S Web of Conferences 21, 01013 (2017)

19. Tyurin, A., Kuvataev, I., E3S Web of Conferences 174, 01059 (2020)

20. Stala-Szlugaj, K, Grudzinski, Z., E3S Web of Conferences 10, 00089 (2016) 